\title{
オキシン含浸ろ紙を固定相とする希土類元素の クロマトグラフィー
}

\author{
永井 英夫*，清島 紘生**
}

(1971 年 4 月 26 日受理)

\begin{abstract}
酶酸ーフェノールーオキシンー水の混合溶媒系が，2液相に分かれる条件を，逆相クロマトグラフ的に 利用して，乃紙上で希士類元素の分離を行なった． 14 種の希土類元素は，2成分混合試料では，セリ ウムとプラセオジムの場合を除けば，他のすべての隣接元素の組々合わせにおいても分離の判別が可能 であった。な打， 3 成分系ではネオジムーガドリニウムーホロニウムおよびランタンージスプロシウムーツ リウムが，4成分系ではランタンーネオジムーガドリニウムーホロニウムが，5成分系ではランタンーセリ ウムーネオジムーガドリニウムーホロニウムが分離できた。最良の結果は，オキシン $1 \mathrm{~g}$ を $95 \%$ エタ， ール $145 \mathrm{ml}$ に溶かし, 直径 $11 \mathrm{~cm}$ の円形ろ紙（東洋汇紙 No. $5 \mathrm{~B}$ ) 100 枚を処理した含浸ろ紙上で, $1 \%$ 酶酸水溶液にフェノールを飽和 $\left(25^{\circ} \mathrm{C}\right)$ させた溶液 $100 \mathrm{ml}$ にオキシン $2 \mathrm{~g}$ を溶かし， 2 相に分か れた液層の上層部を展開剂に使用した場合に得られた。
\end{abstract}

\section{1 緒言}

ペーパークロマトグラフィーは，いろいろのクロマト グラフ操作法のうちで, 最も取り扱いが簡易であるが, この方法を逆相クロマトグラフィーに忘用する場合に は, 安定な固定相を得るための前処理が煩雑である上 か, 取り扱いうる試料量がごく微量に限られるなどの欠 点を伴いがちであった．これらの欠点を補う一方法とし て, オキシン含浸ろ紙は簡単な熱処理で安定な逆相用固 定相が得られるので，この固定相によるクロマトグラフ ィー在研究することにした．固体固定相の表面に分配機 構上必要な液相をつくるために, 本研究では, 化学構造 上，固定相であるオキシン分子の一部であるフェノール を主成分とした溶媒系を展開剤として用いることにし た. この方法による希土類元素の分離結果が，従来の才 キシン含浸ろ紙を用いた吸着クロマトグラフィー1) 12) よりも，かなりすぐれた結果が得られたので，報告す ๖.

\section{2 実験}

\section{1 試 薬}

特記したもの以外は，市販特級品をとのま安用いた。 また希土類元素は関東化学株式会社製，酸化物 $99.9 \%$

* 熊本大学理学部化学教空 : 熊本市黑髮町

** 防衛大学校化学教室 : 神奈川県横須賀市走水 1 丁目
のものを用いた。

\section{2 試料溶液}

14 種の希土類元素は, 硝酸塩の形で 1 イオンあたり約 $2.5 \mathrm{mg} / \mathrm{ml}$ 裖度の 水溶液它つくり, それらから次のよ うな試料群をつくった，その場合の各イオンの濃度は, 各イオンあたり約 $0.5 \mathrm{mg} / \mathrm{ml}$ になるようにした.

ランタンーセリウム，セリウムープラセオシム，プラセ オジムーネオジム，ネオジムーサマリウム， サマリウムー ユーロピウム，ユーロピウムーガドリニウム，ガドリニ ウムーテルビウム，テルビウムージスプロシウム，ジスプ ロシウムーホロニウム，ホロニウムーエルビウム，エルビ ウムーツリウム, ツリウムーイッテルビウム，イッテルビ ウムールテチウム，セリウムーネオジム，セリウムーサマ リウム，セリウムーユーロピウム，セリウムーガドリニウ ム，セリウムーテルビウム，セリウムージスプロシウム， セリウムーホロニウム，セリウムーエルビウム，セリウ ムーツリウム，セリウムーイッテルビウム，セリウムール テチウム，ランタンープラセオジム，ランタンーネオジ ム，ランタンーサマリウム，ランタンーユーロピウム， ラ ンタンーガドリニウム, ランタンーテルビウム, ランタ ンージスプロシウム， ランタンーホロニウム， ランタンー エルビウム, ランタンーツリウム, ランタンーイッテルビ ウム, ランタンールテチウム，ネオジムーユーロピウム， ネオジムーガドリニウム，ネオジムーテルビウム，ネオジ 
ムージスプロシウム， ネオジムーホロニウム，ネオジムー エルビウム，ネオジムーツリウム，ネオジムーイッテルビ ウム，ネオジムールテチウム，ネオジムーガドリニウムー ホロニウム，ランタンージスプロシウムーツリウム，ラン タンーネオジムーガドリニウムーホロニウム，ランタンーセ リウムーネオジムーガドリニウムーホロニウム．

\section{3 オキシン処理ろ紙}

オキシン $1.0 \mathrm{~g}$ を $95 \%$ エタノール $145 \mathrm{ml}$ に溶解し た溶液に，直径 $11 \mathrm{~cm}$ の円形万紙（東洋沪紙 No. 5B) 100 枚を浸し，溶液を残らず吸い取らせる。しばらく放 谓して各ろ紙の含浸状態が均一になったところで，室内 に広げて乾燥させる．生かわきのときに約 $90^{\circ} \mathrm{C}$ の空父 浴中に入れると，オキシンは溶融状態となってろ紙に㴆 透するので, 約 5 分間おいて取り出し，ただちにシリカ ゲルを入れたデシケーター中に移して冷却させる・実験 のつど，この含浸ろ紙它取り出して使用する。

\section{4 展開剤}

フェノール $170 \mathrm{ml}$ を $1 \%$ 酰酸水溶液 $1 l$ に加え, スターラーで約 30 分間かき混ぜ， 2 層に分かれるのを 待つ (6〜10 時間ぐらい). 完全に 2 層に分かれてから その上層液 $500 \mathrm{ml}$ をとり，スターラーでかき混ぜなが らオキシン $10 \mathrm{~g}$ を加える. 約 30 分間かき混ぜたのち, 2 層に分かれるのを待ってその上層液を展開用として使 用する，上述の操作はすべて $25^{\circ} \mathrm{C}$ の恒温そうを使用し て行なった。

\section{5 展開操作}

展開装置と展開要領はすべて既報912)に準じて行なっ た、ただし展開液温は $25^{\circ} \mathrm{C}$ とた。をた含浸ろ紙中央 部にそう入する無処理万紙は， $3 \times 20 \mathrm{~mm}$ のものを使用 し，含浸ろ紙と展開剂表面との距離は 6〜7 $\mathrm{mm}$ とし た. 展開は溶媒先端が原点から約 $3 \mathrm{~cm}$ のところに達す るまで行なった。

\section{6 帯域の検出}

展開完了後のクロマトグラムは，これを 2 等分し，一 方はアンモニア蒸気にさらし，他方には $0.2 \%$ アルセナ ゾIII（ドータイト）水溶液を噴霧する。带域は最初の 半分では主として黄色采の着色を呈し，あとの半分では 主として青緑色に着色する。これらの実験例を Fig. 1 に 示した。このように眼報の場合 ${ }^{12)}$ と比較して，2成分系 と 3 成分系では分離結果がすぐれている。 \&た，吨報で は4 成分系以上の分離はできなかったが，本研究では 5
成分系までの分離が可能である。

\section{3 考察}

本研究は咋報のオキシン含浸ろ紙を用いる沈殿ク口 マトグラフィー1) 11) および低溶解度クロマトグラフィ -12) と操作法注類似しているが，分離機構は上述の方法 が一種の吸着クロマトグラィーと夕なされるのに対し て，本研究の場合は分唯機構の主因子は分配であると推 測している。この推定を確かめるために，次のようは実 験を行なった。

フェノールで飾和した $1 \%$ 酶险水溶液にオキシンを過 剩に加えれば，容器の底に沈殿したオキシンのすぐ上に 赤かっ色の液相索生じ，さらにその上にとう黄色の液相 が生ずる，この 2 種の液相は成分種は同一であるが成分 比が異なっている。したがってオキシンと錐体をつくる 金属イオンは両相に違った濃度で保持され，分配が生ず る.このように界面穵接して両相にオキシンを含有しな がら違った成分比の液相が安定に生ずる溶媒系として， 酢酸ーフェノールー水の溶媒系を用いた点が本研究の特色 である。このような 2 液相は，オキシン含没る紙をオキ シンで飽和した，フェノールー酢酸一水溶媒系に浸したと きにも当然生ずると予想され，固体オキシンに接して生 ずる液相は固定相として働くものと思われる．以上が本 実験でのイオン分離の主機構学分配と推定した根拠であ る.

このようにして生じた固定相液相は，かなり多量が安 定に担体上で保持されると考えられる.

酢酸の䟴度を $1 \%$ と決めたのは，往来の方法1) 12) 同様に，pH を調節することによって，才キシン錯体の 見かけ上の安定度を加減して, 目的とする希土類元素イ オン間の分離に適切な濃度を実験的に見いだしたもので ある.

\section{4 結諭}

化学構造上，才キシン分子の一部をなしているフェノ ールを酰酸水溶液に飽和した溶媒にオキシンを過剩に加 えれば，適当な条件では，容器の底に沈殿したオキシン 固体上の液相は 2 相に分かれ，これらの 2 相は界面を接 乙て安定に存在しながら，組成成分比が異なっている。 したがってオキシンと鈚体をつくる金属イオンは，これ ら 2 相に分唒される. この現象老逆相クロマトグラフィ 一に利用して希土類元素の分離に用いた結果，征来の才 キシン它国定相とする吸着クロマトグラフィーよりもす ぐれた結果が得られた。

本研究では，逆相クロマトグラフィーの場合にいるい 

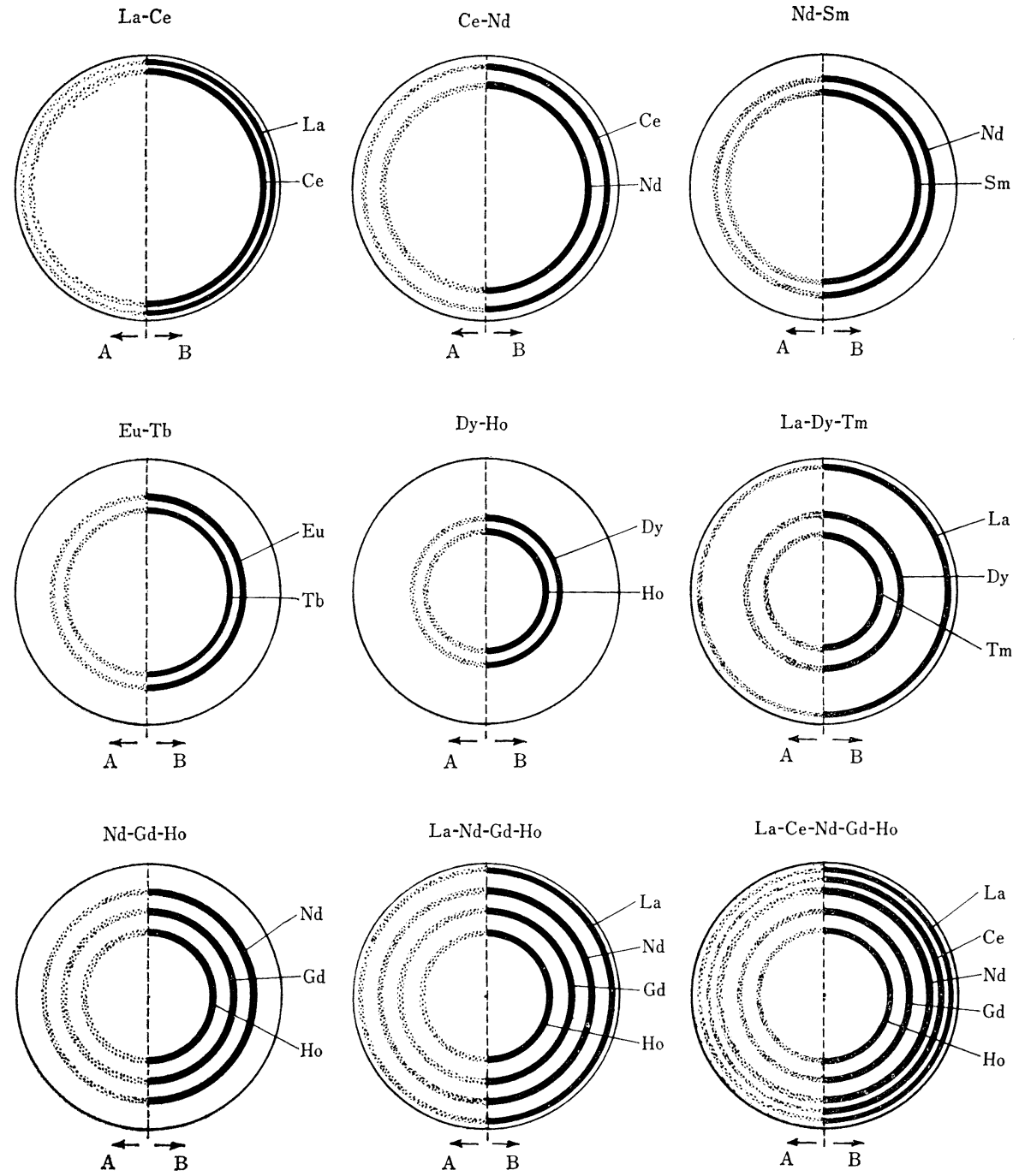

Fig. 1 Schematic diagrams of mixtures

A : Chromatograms after sprayed with $0.2 \%$ Arsenazo III aq. soln. all kinds of metal zones coloured in light green; B : Chromatograms after exposed to ammonia vapour most metal zones coloured in yellow, but La (grayish yellow, white fluorescence), Ce (brown), Dy (light brown)

ろ問題になる担体と，それに保持される分配用固定相液 相が，簡易かつ確実に保持されると思われる点は，特色 としてあげられる。

\section{交献}

1) 永井英夫：日化， 76，1246（1955).

2) 永井英夫: 同上, 77, 1267 (1956).

3) 永井英夫 : 同上, 77, 1794 (1956).

4) 永井英夫 : 同上, 78, 285 (1957).

5) 永井英夫 : 同上, 78, 840 (1957).

6) 永井英夫 : 同上, 78, 1334 (1957).
7) 永井英夫，料池 健：同上， 81，1271 (1960).

8) 永井英夫, 西山环世：同上, 82，347 (1961).

9) H. Nagai : Bull. Chem. Soc. Japan, 33, 715 (1960).

10) H. Nagai : ibid., 37, 1076 (1964).

11) 永井英夫：本誌， 15，50 (1966).

12) 永井英夫，山崎育子：同上，16，95 (1967).

Chromatographic separation of lanthanides on a circular filter paper impregnated with oxine as the immobile phase. Hideo NAGAI* and Hiroo KiYoshima** (*Department of Chemistry, Faculty of 
Science, Kumamoto University, Kurokami-machi, Kumamoto-shi; **Department of Chemistry, Defense Academy, Hashirimizu, Yokosuka-shi, Kanagawa-ken)

Separation of lanthanides by reversed phase chromatography was carried out on an oxine-impregnated filter paper on the condition that lanthanide ions might be partitioned between the two liquid phases which appeared when aq. acetic acid solution was added with phenol and oxine. The following sample solutions were effectively separated; binary mixtures of La-Ce, Pr-Nd, Nd-Sm, Sm-Eu, Eu-Gd, Gd-Tb, Tb-Dy, Dy-Ho, Ho-Er, Er-Tm, Tm-Yb, Yb-Lu, $\mathrm{Ce}-\mathrm{Nd}, \mathrm{Ce}-\mathrm{Sm}, \mathrm{Ce}-\mathrm{Eu}, \mathrm{Ce}-\mathrm{Gd}, \mathrm{Ce}-\mathrm{Tb}, \mathrm{Ce}-\mathrm{Dy}, \mathrm{Ce}-$ $\mathrm{Ho}, \mathrm{Ce}-\mathrm{Er}, \mathrm{Ce}-\mathrm{Tm}, \mathrm{Ce}-\mathrm{Yb}, \mathrm{Ce}-\mathrm{Lu}, \mathrm{La}-\mathrm{Pr}$, La-Nd, La-Sm, La-Eu, La-Gd, La-Tb, La-Dy, La-Ho, LaEr, La-Tm, La-Yb, La-Lu, Nd-Eu, Nd-Gd, Nd-Tb, $\mathrm{Nd}-\mathrm{Dy}, \mathrm{Nd}-\mathrm{Ho}, \mathrm{Nd}-\mathrm{Er}, \mathrm{Nd}-\mathrm{Tm}, \mathrm{Nd}-\mathrm{Yb}$, and $\mathrm{Nd}-$ $\mathrm{Lu}$, ternary mixtures of Nd-Gd-Ho and La-Dy-Tm, quaternary mixture of $\mathrm{La}-\mathrm{Nd}-\mathrm{Gd}-\mathrm{Ho}$ and cinquenary mixture of $\mathrm{La}-\mathrm{Ce}-\mathrm{Nd}-\mathrm{Gd}-\mathrm{Ho}$. In all cases the separation of $\mathrm{Ce}-\mathrm{Pr}$ were not clear.

The most widely applicable developing solvent was made as follows: $100 \mathrm{ml}$ of $1 \%$ acetic acid solution saturated with phenol at $25^{\circ} \mathrm{C}$ was added with $2 \mathrm{~g}$ oxine and allowed to stand till the liquid phase separated into two layers, the upper layer of the solvent was used as the developer. In this case the filter paper treatment was carried out as follows: 100 sheets of $11 \mathrm{~cm}$ circular filter paper (Toyo-roshi No. $5 B$ ) were immersed in the solution of $145 \mathrm{ml}$ ethanol $(95 \%)$ in which $1.0 \mathrm{~g}$ oxine was dissolved, then dried in an air bath at $c a .90^{\circ} \mathrm{C}$. Developing was done as the routine circular paper chromatography inserting a narrow strip of untreated filter paper in a slit which was cut at the center of the oxine-impregnated filter paper.

The developing was continued till the solvent front reached at $3 \mathrm{~cm}$ distance from the center of the filter paper. The chromatogram thus obtained was cut into two pieces and then the detection of the ionic bands was carried out as follows: one of the semicircular chromatogram was exposed in ammonia vapour, then the ionic bands coloured in yellowish concentric semi-circles; the other piece of chromatogram was sprayed with $0.2 \%$ aq. solution of Arsenazo III, then the ionic bands coloured in greenish concentric semi-circles.

(Received Apr. 26, 1971)

\title{
高周波ポーラログラフ法による $p$-トルエンスルホン酸の定量*
}

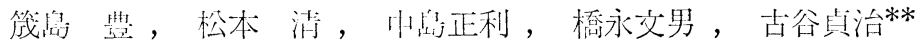

(1971 年 4 月 30 日受理)

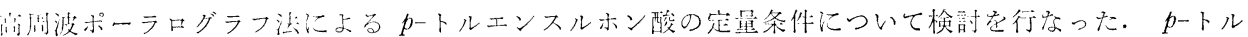
エンスルホン邽は $1 M$ 硫酸アンモニウム $-0.36 N$ 硫酸沾るいは $1 M$ 硫酸マグネシウム $-0.36 N$ 硫酸中

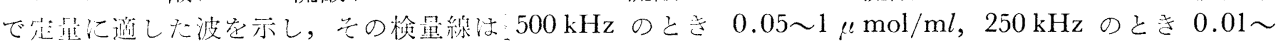
$0.2 \mu \mathrm{mol} / \mathrm{ml}$ の箟囲内でいずれも原点它通り良好な直線性を示した。この波は硫酸塩またはリン酸塩

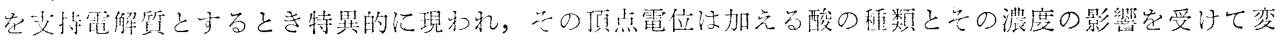

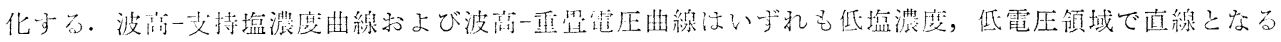

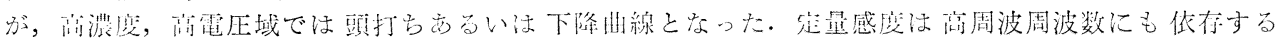
が，ての凨波数別感度は支持程の租颣によって左有される。
\end{abstract}

\section{1 緒 $\overrightarrow{\overline{\overrightarrow{1}}}$}

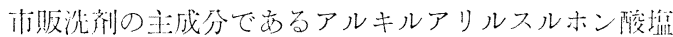

(ABS) の定星法としては，アニオン活性剂がメチレン

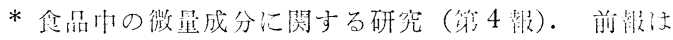

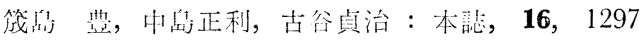
(1967)

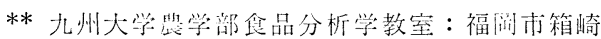

ブルーなどと容易に結合物を形成し有機溶媒で抽出可能 と宗ることを利用した容量法1) 6) (メチレンブルー㵜定 法尔よびその類似法）と比色法》～14（メチレンブルー比 他法教よびその類似法）が多く用いられている。

低分子スルホン酸，新かむずくp-トルエンスルホン 䧣壏は洗剂の物理的性質を变える目的で加光られる。 Epton²) J Jonesi) によって指摘きれているように，ア ニオン界面活性剂とメチレンブルーおよびその颣似化合 